\title{
Finding a Concrete Utopia in the Dystopia of a 'Sub-city'
}

Research in Drama Education: The Journal of Applied Theatre and Performance

Selina Busby

Royal Central School of Speech and Drama, University of London, London.

\section{Selina.Busby@cssd.ac.uk}

Keywords: utopia; Dharavi; youth theatre; change.

Selina Busby is Principal Lecturer in Community Performance and Applied Theatre, and course leader for the MA Applied Theatre at Royal Central School of Speech and Drama, University of London. She is an applied theatre practitioner who works in prison settings and with young people both in the UK and internationally. Her research focuses on theatre that invites the possibility of change, both through contemporary plays and participatory performance.

\section{Abstract}

This article examines a ten-year long series of annual short-term interventions with young people living in Dharavi (India) that has led to a number of public theatre events. The partnership offers a unique training experience to students from the UK in theatre facilitation, and a regular opportunity to participate in theatre for young people in Dharavi. It brings together students from The Royal Central School of Speech and Drama (University of London), working collaboratively with an Indian theatre practitioner, an NGO based in Mumbai, and young people who live in Dharavi. In the article, I explore the role theatre plays in the precarious lives of those who live in Dharavi, and the potential of this on-going partnership to develop a theatre of change in a community and site affected by extreme poverty. Focusing on the longevity of this applied theatre project and drawing on the writing of Paul Ricoeur on utopia, I argue that this on-going exchange can be understood both as a form of cultural invasion and, at the same time, a utopian community theatre practice. Whilst the project continues to raise troubling questions about cultural colonisation and power, the integrated investment of partners and participants over time has generated a resilient sense of optimism as well as, to a more limited degree, evidence of long-term positive change.

I have worked in Dharavi (India) with students from The Royal Central School of Speech and Drama for the decade that runs from 2006 until 2016. Dharavi, a 'sub-city' in the heart of Mumbai, is a unique and complex place and the people who live there lead a precarious existence. They have no legal status and no postal address in many cases, and live in homes that were built illegally, leaving many of them deprived of basic rights and services. With an estimated population of over one million people packed into a square mile, Dharavi plays host to as many people as the UK's second city of Birmingham, but in one percent of the 
space. Since our work started in Dharavi, I have reflected on it in the light of Syed Jamil Ahmed's wish 'for a world without theatre for development' and his critique of projects that use theatre as a means 'for transmitting development messages' (Ahmed 2002; 2010). More recently, I have considered our work by making use of James Thompson's call for the end of an applied theatre practice that privileges 'effect' and his positioning of a radical theatre practice as in alignment with an aesthetics and politics of affect (2009). In this article, I ask myself where this project might sit on that scale as well as about the ethical implications of exporting our students and our UK based approaches to a slum region in India. I consider the possible reasons why the young people in Dharavi make the space - both temporally and spatially - to create theatre with us each year. In particular, I focus on how community theatre with slum dwellers might work to engage the social imagination, allowing for a reexamination of the present and opening the way for participants to configure a different future: a utopia or a productive imagining of something else entirely. Drawing on the concept of utopia offered by Paul Ricoeur in his writing on the social imagination, where utopia is not only a dream but 'a dream that wants to be realised' $(1986, x x i)$, I explore our work in the urban community theatre setting in Dharavi and consider whether or not our theatre-making might create moments where change is possible, and if so, the extent to which these might be argued to enact a form of cultural invasion or utopic possibility. The intervention explored here is a form of what I am calling a pedagogy of utopia. Ricoeur describes the 'social imagination' as both constructive and destructive, offering both confirmation, and constitution, of the present. Because the social imagination responds to what is, it can therefore critique it and question it. Once a questioning of the present occurs, alternatives may be imagined. The practice of social imagination can then configure a utopia or, as Ricoeur writes, a 'productive imagining of something else ... from this elsewhere, it is possible to look back to where we have come from and re-examine the present, which now looks strange and opens up the field of the possible' $(1986,266)$.

One role of community theatre, a role that was manifest in the Dharavi project, might be to open this 'field of the possible' through which participants see beyond the real to a field that allows for the belief in an alternative way of living to emerge. Arguably, it is the role of those who facilitate theatre-making to create moments where this is possible. In this way 'imaginative variations on the topics of society, power, government, family, religion' (Ricoeur 1986, 16) can be created. A utopic community theatre practice, therefore, confronts the challenge of creating a better future by exploring what could be, by questioning social reality and by challenging the assumption that there are no alternatives. It is a theatre practice that reflects what is, but in doing so it paves the way for what is not yet.

'Utopia' is a word that has been discredited and, as social geographer David Pinder comments, the growth of neoliberalism dictates that change is no longer possible as it is widely accepted that there are no alternatives to the current social structures (Pinder 2005). The year 2016 is the five hundredth anniversary of the publication of Thomas More's first use of the word in Utopia, and so revisiting the concept is perhaps timely. My approach to the concept echoes that of historian Russell Jacoby, who distinguishes between a 'blueprint tradition' and 'iconoclastic tradition' of utopian thought, stating that his 'wish to save the spirit, but not the letter, of utopianism' draws him to the iconoclastics 'who dreamt of a superior society but who declined to give it precise measurements' $(2005, \mathrm{xx})$. Aiming to use 
the term without prescribing the visions of the future that may be glimpsed with it, I also turn to Dolan's exploration of utopia and live theatre. Dolan argues that when active spectators come together what emerges is a 'capacious sense of a public, in which social discourse articulates the possible rather than the insurmountable obstacles to human potential' $(2005,2)$. This sense of 'social discourse articulating the possible' underpins my understanding of the practice in Dharavi. This is not to say that the intention of the work is to make change happen, but that, for me, the intention is for the participants to experience the potential to imagine change. The intention of this utopian community theatre is to change reality, or rather, to create an environment that will invite the kind of reflection in which change is both desirable and conceivable. This potential for alternatives may be glimpsed when the 'field of the possible' is opened. In these moments, a gap is created between what exists and the utopian vision produced by the imagination. When theatre invites people to fill these gaps with their imaginative projections, people become positioned as potential agents of change. I return to discuss this concept in more depth later, when asking if the Dharavi theatre project offers participants a new form of colonisation that preserves exploitative and oppressive power structures (and thus creates an unrealisable fantasy) or if it is, indeed, a means for shattering the present order.

\section{Dharavi: A 'sub-city'}

The Dharavi project started as a student project on the BA (Hons.) Drama, Applied Theatre and Education at the Royal Central School of Speech and Drama (Central). It originally involved five students who worked with a group of young people from the 'sub-city' to create a piece of theatre over four weeks in June 2007. My own role was to support the students and participants in the process and to assess the former on the unit they were studying for their degrees. While in India the students were supported by an Indian colleague (Divya Bhatia) and a translator (Satish Deembe). This team has not changed over the years: while the individual students and some of the young participants change from year to year, the partnership between Central, Bhatia, Deembe and myself has remained intact. The word translator, as I tell the students, underestimates Deembe's role; Deembe is a creative and dynamic theatre practitioner in his own right. He worked originally as an assistant to Bhatia, himself an apprentice who graduated from a participant in a community project to trainee facilitator.

In the eighteenth century the area Dharavi is situated in was a swamp and in the early nineteenth century it became a fishing village for migrant workers. Now it is somewhat infamously (and probably inaccurately) known as the 'largest slum in Asia' (BBC News 2015). It attained world-wide fame through Danny Boyle's film Slumdog Millionaire (2008), where it is portrayed as a violent, dirty, pest-ridden warren without services or sanitation. In the UK it also featured in a Channel 4 documentary titled Slumming It (2010), presented by the popular television personality Kevin McCloud. In this programme McCloud explores, in part, a more positive image of the communities there, describing them as 'some of the happiest and most beautiful I've seen' (2010). Whilst McCloud extols its community spirit, the visuals in the documentary communicate a more negative picture, leading the Indian authorities to accuse the film and McCloud himself of 'damaging the country's tourism industry by making "poverty porn"' (Singh 2010). 
Dharavi is alternately perceived as a squalid eyesore or romanticised as a place where 'real' community feeling is extolled. More prosaically, it is a collection of settlements, each with its own identity. Several localities within Dharavi are distinct from one another in terms of communities and history, just like any other city, except that it is found within the boundaries of the much larger city of Mumbai and is particularly densely packed. Mumbaibased journalist Kalpana Sharma sets out the history and people of the area and the 'subhuman conditions' in which they live, explaining that Dharavi's current manifestation dates from 1909. Originally found on the outskirts of Bombay, as Mumbai was known at the time, Dharavi now finds itself in the very centre of Mumbai (as the city has expanded), where it occupies a prime location highly prized by developers. Today Dharavi sits between the two main Mumbai suburban railway lines and water and sewer lines have been added around the houses and buildings. Two main roads cut across and through the area. Containing 'twenty-seven temples, eleven mosques, and six churches' (Sharma 2000, ix), it's sheer size can be daunting. It has retail shops, warehouses, goods transport companies, lawyers, accountants, hotels and entertainment businesses, health clinics and an estimated GDP of over $\$ 1.5$ billion, all established illegally on land not owned by its residents. Joseph Campana laments that it is not considered a city in its own right, stating that 'tradition, entrenched attitudes and colonial-era ideas about cities consign Dharavi, in the minds of the country's middle classes and elites, to the status of an urban blemish - a slum' (2013, iii). Yet in both size and scope, Dharavi is a city with a population as cosmopolitan as that of Mumbai itself. It is a city within a city, or rather, a sub-city that contains the very poor and destitute as well as thriving businesses that employ a large proportion of the population. Its industries contribute to the global economy as legitimate businesses, while its residents have no legal status, property ownership or access to government services (Sharma 2013, $\mathrm{x})$.

The people who live there lead a precarious existence. Families of fifteen or more often live in 300-square-foot homes. Homes that were built illegally (on land not owned by the builders) are now rented illegally, hence their present occupants' legal non-status. Most dwellings in Dharavi are in need of sanitation and adequate clean water. In a place where space is at a premium, areas serve multiple purposes: street, lunchroom, playground, political meeting place, pathway, production line and drama workshop all occupy the same patch, often at the same time. Homes double as factories, offices, recycling centres and shops. Dharavi runs twenty-four hours a day, with people (including the young) often working long days for little return. Sharma observes that it is not simply 'a chaotic collection' of people and structures; it is a vibrant collection of individuals, families and communities 'who have figured out a way to survive in the most adverse' of conditions. She cautions that such a situation should not be romanticised, since 'there is nothing to celebrate about living in cramped houses with no natural light or ventilation or water and sanitation ... no one should live in such conditions' $(2000, x x)$. The lack of private toilets and sanitation mean that people use overcrowded public facilities, or they simply urinate and defecate directly into the river, and when the monsoon rains flood the city each year this river water floods the pavements and floors of Dharavi. The UNDP Human Development Report 2006 claimed that there was, on average, one toilet for every 1,440 people in the sub-city. The mortality rate in Mumbai's slums is reportedly fifty percent higher than that of the surrounding areas (Jacquemin 1999, 90-91). 
Within this sub-city, each year about six students from Central create theatre with some of the young inhabitants of Dharavi, often working in cramped and overcrowded, makeshift spaces in rooms above churches or temples, or in storerooms. The work is always improvised and draws on the skills and interests of the participants, who decide the themes and content of the final performances. We work in partnership with an NGO, a Dharavibased non-profit organisation committed to investing in women's health and young people's education as a means to building viable urban communities. The organisation has operated for over twenty years, working at the community level to encourage slum communities to become catalysts of change in their own right. ${ }^{1}$

\section{A 'pluriverse' in Dharavi}

We were initially invited to work with a group of young people who identified themselves as living with domestic violence, and who volunteered to take part in a drama project. During the first year, the NGO set the objective that these young people would begin to perceive the possibilities of a different future. For the NGO, this meant would improving the young people's job prospects which in turn meant that they must learn English. The NGO works with the least advantaged inhabitants of the area. Many of the young people are homeless even by Dharavi's standards, and many lack responsible adults in their lives. Most live, work and attend school within Dharavi and rarely, if ever, move beyond the sub-city's boundaries to venture into Mumbai itself. Those young people who do work do so 'in day-long 9 to 6 shifts at the plastic recycling units', only attending school once their shifts finish (Ghosh 2014).

Bhatia and I wanted to work with a dialogical performance practice that would enable two groups of young people who would not meet under ordinary circumstances to exchange ideas creatively. We were interested in using theatre to support the development of what Ramion Panikkar calls a 'pluriverse': a place in which intercultural dialogue involves a 'mutual opening up to the concern of the other, a sharing in a common higher value that both parties acknowledge and neither party controls' $(1995,78)$. Intercultural dialogue, according to Panikkar, is a process of identifying one another's assumptions and seeing the other not with a goal of change or development, but an openness to plurality rather than oneness. Our aim was to facilitate the Dharavi inhabitants and Central students to engage in dialogue and create a piece of performance together that would celebrate this pluriverse. Panikkar describes dialogue as a practice that is instigated by local people, the aim of which is to 'create local autonomy using local knowledge which will be mediated by the process of globalisation and knowledges, developed through exchange to remain autonomous and individual' $(1995,78)$. We hoped the work would enable young people from different contexts and cultures to learn together through a dialogic practice that did not privilege either group. We developed our dialogic theatre events and the devising process allowed for exchange in which participants remained autonomous whilst working mutually to encounter different world views and experiences creatively.

Since 2006, the project has taken different forms, but each year the students and the Dharavi participants have worked together for five weeks coming together for four or five evenings a week in three-hour sessions, with a break for chai and street food midway through. The sessions have involved a range of theatre-devising techniques and skills- 
sharing. These sessions have included an exchange of puppet-making skills from both India and the UK, the teaching of Bollywood musical numbers in exchange for street dance routines, Indian pop music with British and American pop music, classical Indian dance and storytelling games, along with a range of devising techniques from across the world. The process moves towards creating a performance to be performed by the young people for audiences invited by the young people and the NGO itself. The subjects of the performances are generated in the early workshops and are decided by a process of collective decisionmaking by the young people.

During the first year we worked with twenty-five to thirty participants between the ages of twelve and twenty-two. Each year has seen growth in both numbers of participants and age ranges, such that in 2014 we worked with sixty participants between the ages of eight and sixty. It became clear from conversations with participants of all ages that they viewed the performances as a way to share concerns about a range of issues affecting their communities. Performances have focussed on domestic and sexual violence; gender, sex and caste inequality; and education, health and sanitation issues. Participants frequently speak of dreams of Bollywood stardom. Over the years I have come to see the work as a sustained, deeply embedded practice: one that is relatively brief each individual year, but which develops year by year and is of value to those involved. This sustained involvement is a long-term commitment and has become embedded in the rhythms of Dharavi, the NGO, and Central, as well as each of the staff members involved. It has also become embedded in the yearly cycle of the young people, who make space in their routines of school, work and chores to take part. The project runs each year at the same point, just as the heat builds and the monsoon breaks, and it has become as reliable as the annual rains and is anticipated as much, as the young people tell me. I have begun to think of the project as a practice of integrated investment, in that it pulls together a diverse group of people to combine their skills as a unified, temporary but continuous community that generates mutual benefit.

The difficulty is that whilst we have been aiming for a pluriverse which does not privilege one group over the other, we have also been working within the NGO's objective that the participants learn English. This immediately creates a hierarchy which has the Dharavi young people at a disadvantage, placing their local language in a subordinate position to that of the students. It also brings our 'first-stage' utopic dream to an abrupt end with an arguably deeply regressive practice that could be described as a cultural invasion that reinforces colonial tropes. As the applied linguist Suhanthie Motha notes, the teaching of the English language contributes to 'the international dominance of English, associated with its Whiteness, wealth, power and cosmopolitism' (2014, xxi). Sahith Aula observes that English is the language of the elite classes and the government in India and that only 30 percent of the population speak it (2014). English is still the language of government documentation and yet many government (or State) schools do not teach English, while the elite and middle classes send their children to private English teaching schools. For Aula, knowledge of English language has become a form of discrimination, originally instigated by British colonialism, and continued today to the particular disadvantage of the poor and those from lower castes. Yet the NGO sees the development of English skills as important and the young people themselves are often keen to experiment with their English skills. It is evident that English plays a paradoxical role here. Our privileging of the English language reinforces inequalities in terms of both race and caste, but also provides Dharavi inhabitants access to 
the English language that in turn offers a positive means of addressing the discrimination that Aula identifies.

\section{Finding hope}

Dolan suggests that hope can be found in theatre because it articulates the possibility and not the infeasibilty of change (Dolan 2005). There is hope to be found in this project in the contradictory function of the English, as it potentially both confirms and contests colonial attitudes to the use of langage. This paradox acknowledges that change may be possible. The NGO encouraged us to see teaching English as a benevolent act that would enable the learners to develop skills in order to seek employment outside Dharavi and lead more prosperous lives. They had no preference for which methods we used, so we chose to use theatre as a 'hook' to engage the participants and allow our students and the young people from Dharavi to play in a place where play is hard to come by, both spatially and temporally. This also created space for our students to train as theatre facilitators, and for the young Dharavi people to take part in a skills exchange that was unusual for them.

Throughout the early years of the project, the young people talked with the students via our translator, Deembe. Both groups of young people shared stories about everyday life, school, families, friends, work and aspirations, and these conversations found their way into improvisations. It became apparent that the Dharavi youth saw little prospect of change in their lives. They were curious about life in England and other places, but talked about settling down and raising families in Dharavi. The theatre they wanted to create concerned Dharavi life and the issues they wanted debated there. The first year's work was about family violence, and the next year focused on homophobia. Their lives, like those of many young people, were centred on the place in which they were growing up. In the second year of the project, when working on a mapping exercise that created an installation depicting Dharavi, they created a path through sculptures created by newspaper, plastic bottles and strips of material, filling the space with found items, but they left small spaces in which they sat alone or in groups of two or three. When talking about the piece, one of the young women, acting as spokesperson for the group, described Dhavari as 'madly busy, always moving, loud, dusty and yet safe, with secret moments of calm and peace ... home'.

That year the group was keen to polish their performance skills and wanted to perfect some Bollywood dance routines. They talked about their dreams of escaping through being discovered as a Bollywood star. One young woman told us that she had been waiting for us to come back, because she knew she wasn't good enough to dance in films yet, and wanted another chance to practice. That same year a popular Bollywood film contained a sort of 'hand-jive' of rhythmic slapping and clicking that a group of the boys had perfected and were keen to teach us. They too talked of wanting to be in films. Here the participants were imagining a sort of utopia, a fantasy of a luxurious Bollywood career and lifestyle. They were indulging in a dream of a better life. They longed to live on 'Bollywood Drive' rather than on '60 Feet Road', Dharavi. In this project we have perhaps been guilty of exploiting this fantasy - perhaps even of encouraging it - while at the same time affirming the English language as a means to economic improvement. But it is also possible to see utopic potential in this work. In that second year, as the two groups of young people talked, devised and played together, exchanging puppetry, games and songs while Bollywood dance numbers were 
swapped for street dancing amid much good humour and pleasure, a sense of optimism was tangible. As the participants worked together to create theatre that celebrated same-sex relationships, the young Dharavites improvised stories about their lives and devised theatre that was utopian. Ricoeur comments that 'the result of reading a utopia is that it puts into question what precisely exists; it makes the actual world seem strange ... The utopia though, introduces a sense of doubt that shatters the obvious' (1986, 299-300). The sense of optimism each year as we work with the young people arises through a process of devising theatre that questions 'precisely what exists'. Over the years, the young people have 'made their world seem strange' by raising questions about patriarchal social structures, the caste system, gender equality, education rights, domestic violence, faith and gang violence, and women's health. This long relationship of short-term interventions is utopian perhaps because while talking and devising, the young people are critiquing the social order, and this critique creates the potential for alternatives to be conceived.

Ricoeur lists three levels of utopia. The first is where utopia 'is fancy - the completely unrealizable' (1986, 310). The second is where utopia constructs an 'alternative to the present power' (ibid., 16). Here, a better power replaces the one that exists. At the third level 'utopia is the exploration of the possible' (ibid., 310). This level is the most pertinent here. Ricoeur sees the third-level utopia as being concerned with the possibilities of 'living without hierarchical structure and instead with maturity' (ibid.,, 310). It was his conviction that 'the only way to get out of the circularity in which ideologies engulf us is to assume a utopia, declare it and judge it an ideology on this basis' (ibid.,, 172). At this point it is possible to be within the 'ideological circle' but not entirely conditioned by it. And it is here that change becomes possible: the circle becomes a 'spiral', which allows for reflection and alternatives to be conceived. The spiral stretches the ideological circle so that it is possible to be within it, but still able to reflect on the circle itself. It is a utopia that causes the circle to stretch out into a spiral or a circle with space (or 'gaps') in which the reflection takes place. In The Principle of Hope, Ernst Bloch outlined his own stages of utopia, arguing that once a utopian dream moves beyond abstract fantasy it may become a 'concrete utopia' $(1986,158)$. I would suggest that in the Dhavari project, although the participants have moved beyond the level of the fantasy stage of utopia and now work at the second level, they have yet to reach a 'concrete utopia'. The performances they create are constructing possibilities of alternatives. These performance question what is, and the young people involved dream of a society that is more just by presenting a lively and engaging theatre on a range of social topics that they would like to see discussed (and changed) by the community.

\section{Cultural Invasion and/or Concrete utopianism?}

As we worked in the first year as a group of forty people in the rehearsal room (sometimes street, sometimes temple, sometimes shop front), the Central students and I struggled with the complex ethical dilemmas raised by the project. We focused on the work, on facilitating the theatre process. Students shared their performance skills as facilitators, devisors and directors, and the participants shared their performance skills and traditions, and theatre was created. Now nobody in the room talks about teaching English or works towards that goal as a strategic aim, but by the end of each year the students have learnt some Hindi and 
Marathi and the participants now confidently use some English. This confidence grows each year.

If, as Ricoeur comments, 'the thrust of utopia is to change reality' $(1986,289)$, a utopian theatre practice, and a pedagogy of utopia, can be interpreted as a theatre practice that confronts the challenge of creating change by exploring what could be, by questioning social reality, and by challenging the assumption that there are no alternatives. A utopian theatre reflects Ricoeur's view that a utopia is 'fundamentally realizable', and it is 'only when it starts shattering order that it is a utopia. A utopia is always in the process of being realised' (Ricoeur 1986, 273). The thrust of the Dharavi theatre project is also to change reality, or at least to create an environment that invites the kind of reflection in which change may be both desirable and conceivable.

In order to explore the critical distance required for such questioning, Ricoeur draws on the original meaning of 'utopia' as being 'no-where' or, in Thomas More's terms, as 'no real place, a ghost city':

... we start from the kernel idea of the nowhere, implied by the word utopia itself. From this 'no-place' an exterior glance is cast on our reality, which suddenly looks strange, nothing more being taken for granted. The field of the possible is now open beyond that of the actual; it is a field, therefore, for alternative ways of living. (ibid., 16).

From a position of no-where, the observer ceases to take for granted the present reality. So 'no-where' becomes a reflexive space in which we can become reflexive. This is what is happening in the Dharavi rehearsal room: the cultural exchanges are taking place in a nowhere, a place distanced from the everyday realities of both groups of young people, a place and time where reality looks strange.

Each June as I work in Dhavari, with all my qualms and confused post-colonialist ideas and my unease with one-off, short-term projects that might have no effect (not to mention the very dangers of aiming to have an effect at all), I again experience the tensions surrounding this work. I have become more comfortable, however, over the course of this lengthy relationship. In 2012, during a chai break, a participant brought me a square of chocolate as a gift, and thanked me in English for visiting and making theatre with the group each year. This fleeting moment made me reflect on the students and participants who had taken part in this exchange. I recognise that the Central students change each year, but that many of the Dhavari participants return each time. Twelve of them, in fact, have consistently and continually worked with us each year. These twelve return to work on a new play and they bring friends who also create theatre with us. We create issue-based - but funny, moving and entertaining - performances. During this chai-break moment I reflected on the remarkable nature of that commitment to a four-week-long project once a year, and on the increase in our numbers from forty to sixty. Bhatia informed me that this is the only longterm partnership to take place in Dharavi. How and why do these young (and now not so young) people make the commitment to come back when their lives are often unbelievably precarious, fluid and difficult; why make theatre with our emerging facilitators each year? 
I can hazard guesses about this, and the 'effect' and 'affect' of the work, and although I am more comfortable about the ethical stance of the work now I am still troubled by it. There is, nevertheless, something about this long-term relationship of short-term interventions that is clearly enticing to the people we work with and the NGO who, by the way, have stopped asking for English lessons. Now each year we are asked to create theatre. I also know that they have raised funds for other theatre and performance projects. The Dharavi Biennale, a festival of the arts, is now being taken seriously by Mumbai residents, and in 2015 some of our participants performed at this festival.

The young people do not just talk about Bollywood as their dream now, and they are looking directly at the changes our translator has made in his life as a source of inspiration for developing their own performances and theatre. While the Dharavi participants work in what I call 'a nebulous utopia', our translator, Deembe, has moved through this stage to reach is own concrete utopia. Deembe has moved from participant/assistant to apprentice facilitator, to translator, to running his own applied-theatre projects in Mumbai and Pune, and is now making a living out of doing so and supporting both himself and his family. By 2015, the project consisted of a co-facilitation team made up of six students from Central, six Dharavi students, a translator, an Indian practitioner, myself, and other participants. With this work we have moved into Ricoeur's second stage of utopia, where it becomes possible to imagine a better future, a more positive alternative. Through this process some of the Dharavi participants are training to be facilitators alongside the Central students, and not merely exchanging skills.

But what about third-stage utopia, the 'concrete' utopia that constitutes a possibility of change and 'opens up the ideologically unobstructed view of human hope'? (Bloch 1986, 158). With this extended project, the NGO themselves have demonstrated a change: the work has helped the organisation to position themselves at a distance to their aims, and the organisation is now in a position of 'no-where'. Its members can be observers who cease to take the present reality for granted and imagine an alternative. Ricoeur asks, 'may we not say then the imagination itself - through its utopian function - has a constitutive role in helping us rethink the nature of our social life?' He wonders if 'utopia introduces imaginative variations on the topics of society, family, religion' $(1986,16)$ or, in this case, the use of theatre and English. The NGO are supporting a theatre project in which Dharavi young people facilitate a performance with younger inhabitants. The play that was produced in February 2015 by, for, and with the young people of Dharavi, and without Central, suggests that these participants have moved towards a third-stage utopia, a concrete utopia, but that have not yet reached an actual alternative. They are testing out possibilities. Here, the transition between level two and level three utopia is more nuanced than Ricoeur asserts and there is a more phased progression. For concrete utopia to be achieved by the young people, a testing period of a nebulous utopia was negotiated. In Ricoeur's words, the role of the social imagination, activated by utopian endeavour, is to 'impassionate society ... to move and motivate it' $(1986,296)$. And for me, the training of these theatre practitioners and the theatre they create is a nebulous utopian endeavour that realises a radical performance: a pedagogy of utopia.

But how radical is this intervention overall, this pedagogy? Perhaps what is radical here is the suggestion that a utopia might be glimpsed and that the field of the possible might only 
just be visible. As such, the project sits on a cusp between cultural invasion and radical intervention. Ahmed's 'wish for a world without Theatre for Development' ends with the plea 'let us at least have just plain and simple theatre - theatre that never ceases to "develop", theatre which allows debate, dialogue, reflexivity, dreaming the impossible and the flight to infinity' (Ahmed 2002, 218). The Dharavi project, in its offer of simple theatre, provides some of these things and through this, it may offer more than just a dream of the impossible: a glimpse of an alternative future. James Thompson, drawing on Jacques Rancière, states that 'working in any space through the arts can make no automatic claim to be a disturbance of the broader organisation of who speaks, has a part, or is visible' (2009, 174). Art does, however, create a possible 'ripple of affect', and this ripple can create a disturbance and be part of a political act. Applied theatre can disrupt the sensible. I would suggest that the Dharavi project does this by disturbing the normality of the participants' precarious lives for one month of the year, when they make room to create theatre. The normal organisation of everyday life is disturbed by our arrival, and during the month of June they create theatre that asks political questions. In his conclusion, Thompson asks "How do we sustain a particular disruption of the "disruption of the sensible"? ... How does the patchwork practice of applied theatre bring ... reconfigurations of the world into new alliances with each other?' (ibid., 183). The response arising from the Dharavi project, is in its longevity. The integrated investment of the young people, the NGO, Bhatia, Deembe, Central, and myself to our alliance, and to creating theatre that 'disrupts the sensible' in a precarious sub-city.

\section{References}

Ahmed, Syed Jamil. 2002. "Wishing for a world without "Theatre for Development": Demystifying the case of Bangladesh.' RiDE: The Journal of Applied Theatre and Performance 7 (2): 207-219.

Aula, Sahith. 2014. 'The Problem With The English Language in India.' Forbes Nov 6. Available from http://www.forbes.com/sites/realspin/2014/11/06/the-problem-with-theEnglish-language-in-india/\#58dd830737be [Accessed June 3, 2015]

BBC. 2006. 'Life in a slum.'Available from http://news.bbc.co.uk/1/shared/Spl/hi/world/06/dharavi_slum [Accessed September 30, 2015[

Bloch, Ernst. 1954. The Principle of Hope, Vol. 1. Trans. 1986. Plaice, N., Stephen Plaice, S. and Knight, P. Oxford: Blackwell.

Campana, J. 2013. Dharavi: The City Within. Uttar Pradesh: Harper Collins.

Dolan, J. 2005. Utopia in Performance: Finding Hope at the Theatre. Ann Arbor: University of Michigan Press.

Ghosh, U. 2014.'The Children of Dharavi.' Rediff News. Available from

http://www.rediff.com/news/special/the children-of-dharavi/2014 [Accessed January 1, 2016]

Jacoby, Russell. 2005. Picture Imperfect: Utopian Thought for an Anti-Utopian Age. New York: Columbia University Press.

Jacquemin, A. 1999. Urban Development and New Towns in the Third World. Farnham: Ashgate Publishing.

Masini, Eleonora. 1983. Visions of Desirable Societies. Oxford: Pergamon Press. 
McCloud, Kevin. 2010. 'Kevin McCloud on his trip to India.' Available from

http://www.telegraph.co.uk/culture /tvandradio/6952436/Kevin-McCloud-on-his-trip-to-

India.html [Accessed September 30, 2015]

Motha, Suhanthie. 2014. Race, Empire, and English Language Teaching: Creating

Responsible and Ethical Anti-racist Practice. New York: Columbia University Press.

Panikkar, Raimundo. 1995. Invisible Harmony: Essays on Contemplation and Responsibility.

Minneapolis: Augsburg Fortress Publishers.

Pinder, David. 2005. Visions of the City. Edinburgh: Edinburgh University Press.

Ricoeur, Paul. 1986. Lecturers on Ideology and Utopia. Ed. George Taylor. Taylor George.

New York: Columbia University Press.

Sharma, Kalpana. 2000. Rediscovering Dharavi: Stories from Asia's Largest Slum. New Delhi:

Penguin Books.

Singh, Anita. 'India accuses Kevin McCloud of making "poverty porn" in Mumbai slum programme.' The Telegraph, January 25, 2010. Available from

http://www.telegraph.co.uk/news/7055458/India-accuses-Kevin-McCloud-of-makingpoverty-porn-in-Mumbai-slum-programme.html [Accessed September 30, 2015]

Slumdog Millionaire. Directed by Danny Boyle. United Kingdom: Celador Films Film4 Productions, 2008.

Thompson, J. 2009. Performance Affects: Applied Theatre and the End of Effect. Basingstoke: Palgrave Macmillan.

United Nations Development Programme. 2006. Beyond Scarcity: Power Poverty and the Global Water Crisis. UNDP.

\footnotetext{
${ }^{1}$ Whislt happy for the project details to be disseminated The NGO would rather not be named publicly due to the controversial nature of the work, they are wary of being associated with promoting the 'poverty porn' discussed in the article, as a result of inviting UK students into Dharavi.
} 